\title{
PREVALENCE OF HEPATITIS B AND C VIRAL MARKERS AMONG APPARENTLY HEALTHY RESIDENTS OF THE SOCIALIST REPUBLIC OF VIETNAM (SOUTHERN VIETNAM)
}

\author{
Yu.V. Ostankova ${ }^{a}$, A.V. Semenov ${ }^{b}$, E.B. Zueva ${ }^{a}$, E.N. Serikova ${ }^{a}$, A.N. Schemelev ${ }^{a}$, \\ D.E. Valutite ${ }^{a}$, H.K.T. Huynh ${ }^{c}$, S.A. Egorova ${ }^{a}$, Areg A. Totolian ${ }^{a}$ \\ a St. Petersburg Pasteur Institute, St. Petersburg, Russian Federation \\ ${ }^{b}$ Ekaterinburg Research Institute of Viral Infections of SRC VB Vector of the Federal Service for Surveillance on Consumer Rights \\ Protection and Human Wellbeing, Ekaterinburg, Russian Federation \\ ${ }^{c}$ Ho Chi Minh Pasteur Institute, Ho Chi Minh City, Vietnam
}

\begin{abstract}
The aim of this study was to assess the prevalence of serological and molecular biological markers of viral hepatitis B and C among apparently healthy residents of the Southern Vietnam. The study material was represented by 397 blood serum samples collected from apparently healthy residents of the Southern Vietnam. The ELISA examination for presence of $\mathrm{HBV}$ and $\mathrm{HCV}$ markers involved $\mathrm{HBsAg}$, anti-HBs IgG, anti-HBcore $\mathrm{IgG}$, and anti-HCV qualitative determination. For HBV DNA and HCV RNA detection, nucleic acids were extracted from serum blood, and a test for virus detection was carried out by real-time PCR with hybridization fluorescence detection. Amplification and subsequent sequencing of HBV and $\mathrm{HCV}$ were performed using nested PCR with paired overlapping primers jointly flanking the target regions. Analysis of the overall prevalence of serological markers showed that among the apparently healthy individuals anti-HBsAg and anti-HCV antibodies were detected in 12.3\% (95\% CI: 9.27-15.99\%) and 3.27\% (95\% CI: 1.76-5.53\%) of individuals, respectively. The prevalence of HBsAg in men (19.1\%) significantly exceeded that of found in women (5.9\%), $\chi^{2}=14.688$ with $p=$ $0.0001, \mathrm{df}=1$, calculated odds ratio $\mathrm{OR}=3.751$ (95\% CI: $1.892-7.439)$. Among apparently healthy patients, taking into account HBsAg-positive and negative samples, HBV DNA was detected in 26.95\% (95\% CI: 22.65-31.6\%). HBV phylogenetic analysis showed that subtype B4 prevalence comprised 64.49\%. Subtypes C1 (14.95\%), B2 (9.35\%), C2 (6.54\%), C3 (0.93\%), and C5 (3.74\%) were also identified. HCV RNA was detected in 7 samples, which accounted for $1.76 \%$ (95\% CI: 0.71-3.6\%). Phylogenetic analysis showed that all HCV isolates belong to genotype 6, subtype 6a (100\%).
\end{abstract}

Key words: $H B V, H C V$, viral hepatitis markers, molecular epidemiology, genotype, apparently healthy residents, Southern Vietnam.

\section{РАСПРОСТРАНЕННОСТЬ МАРКЕРОВ ВИРУСОВ ГЕПАТИТА В И С СРЕДИ УСЛОВНО ЗДОРОВЫХ ЖИТЕЛЕЙ ЮЖНОГО РЕГИОНА СОЦИАЛИСТИЧЕСКОЙ РЕСПУБЛИКИ ВЬЕТНАМ}

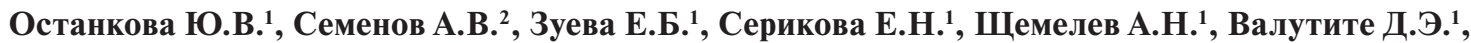
Хуйнх X.K.T. ${ }^{3}$, Егорова С.А. ${ }^{1}$, Тотолян Арег А. ${ }^{1}$

${ }^{1}$ ФБУН НИИ эпидемиологии и микробиологии имени Пастера, Санкт-Петербург, Россия

${ }^{2}$ Екатеринбургский НИИ вирусных инфекций ФБУН ГНЦ ВБ «Вектор» Роспотребнадзора, г. Екатеринбург, Россия

${ }^{3}$ Институт имени Пастера в г. Хошимин, г. Хошимин, Вьетнам

Резюме. Целью нашего исследования было оценить распространенность серологических и молекулярно-биологических маркеров вирусных гепатитов В и С среди условно здоровых жителей Южного Вьетнама. Материал

\section{Адрес для переписки:}

Останкова Юлия Владимировна

197101, Россия, Санкт-Петербург, ул. Мира, 14,

ФБУН НИИ эпидемиологии и микробиологии имени Пастера.

Тел.: 8 (812) 233-20-92. E-mail: shenna1@yandex.ru

\section{Для цитирования:}

Останкова Ю.В., Семенов А.В., Зуева Е.Б., Серикова Е.Н.,

Щемелев А.Н., Валутите Д.Э., Хуйнх Х.К.Т., Егорова С.А., Тотолян Арег А.

Распространенность маркеров вирусов гепатита В и С среди условно здоровых жителей южного региона Социалистической Республики

Вьетнам // Инфекция и иммунитет. 2021. Т. 11, № 6. С. 1131-1140.

doi: 10.15789/2220-7619-TPO-1793

(๔) OstankovaYu.V. et al., 2021

\section{Contacts:}

Yuliia V. Ostankova

197101, Russian Federation, St. Petersburg, Mira str., 14

St. Petersburg Pasteur Institute.

Phone: +7 (812) 233-20-92. E-mail: shenna1@yandex.ru

Citation:

Ostankova Yu.V., Semenov A.V., Zueva E.B., Serikova E.N., Schemelev A.N., Valutite D.E., Huynh H.K.T., Egorova S.A., Totolian Areg A. prevalence of hepatitis B and $C$ viral markers among apparently healthy residents of the Socialist Republic of Vietnam (Southern Vietnam) // Russian Journal of Infection and Immunity = Infektsiya i immunitet, 2021, vol. 11, no. 6, pp. 1131-1140. doi: 10.15789/22207619-TPO-1793

DOI: http://dx.doi.org/10.15789/2220-7619-TPO-1793 
исследования - 397 образцов плазмы крови условно здоровых жителей Южного Вьетнама. Исследование ИФА на наличие маркеров ВГВ и ВГС включало определение HBsAg, anti-HBs IgG, anti-HBcore IgG и качественное определение anti-HCV. Для обнаружения ДНК ВГВ и РНК ВГС нуклеиновые кислоты выделяли из плазмы крови и проводили тест на присутствие вирусов с помощью ПЦР в реальном времени с гибридизационно-флуоресцентной детекцией. Амплификацию и последующее секвенирование ВГВ и ВГС проводили с использованием вложенной ПЦР с парными перекрывающимися праймерами, совместно фланкирующими целевые регионы. Анализ общей распространенности серологических маркеров показал, что среди условно здоровых лиц НВsAg и антитела к ВГС были обнаружены в 12,3\% (95\% ДИ: 9,27-15,99\%) и 3,27\% (95\% ДИ: 1,76-5,53\%) случаев соответственно. Распространенность HBsAg у мужчин (19,1\%) значительно превышала таковую у женщин (5,9\%), $\chi^{2}=14,688, \mathrm{p}=0,0001, \mathrm{df}=1$, рассчитанное отношение шансов OR $=3,751$ (95\% ДИ: 1,892-7,439). Среди условно здоровых пациентов с учетом HBsAg-положительных и отрицательных проб ДНК ВГВ была выявлена у 26,95\% (95\% ДИ: 22,65-31,6\%). Филогенетический анализ ВГВ показал, что распространенность подтипа В4 составляет 64,49\%, также были выявлены подтипы С1 (14,95\%), В2 (9,35\%), С2 (6,54\%), С3 (0,93\%) и С5 (3,74\%). РНК ВГС была обнаружена в 7 образцах, что составило 1,76\% (95\% ДИ: 0,71-3,6\%). Филогенетический анализ показал, что все изоляты ВГС относятся к генотипу 6, подтипу 6а (100\%).

Ключевые слова: ВГВ, ВГС, маркеры вирусных гепатитов, молекулярная эпидемиология, генотипы, условно здоровые жители, Южный Вьетнам.

\section{Introduction}

Hepatotropic viruses, which cause chronic liver diseases, remain one of the most serious public health concerns in the world. Viral hepatitis is the seventh leading cause of death worldwide, and approximately 47 and $48 \%$ of these deaths are associated with the hepatitis $\mathrm{B}$ virus (HBV) and hepatitis $\mathrm{C}$ virus (HCV), respectively. According to preliminary calculations, the cumulative deaths from viral hepatitis in the period from 2015 to 2030 could be approximately 20 million [35].

The epidemiology of viral hepatitis is a dynamic phenomenon subject to change due to socioeconomic development, the development of socio-cultural practices, community activities carried out within the framework of national programs, and the development of hepatitis virus awareness. Currently, great strides have been made in the understanding of viral hepatitis, and ideas about chronic and acute forms of diseases caused by hepatotropic viruses have changed. Methods have appeared that help identify viruses in the early stages or in latent forms of the disease. Antiviral drugs and effective vaccines have been developed against some viruses.

HBV and HCV are found all over the world, and their prevalence differs depending on the geographic region. The worst affected regions with high rates of chronic HBV and HCV infection are in Africa, especially Sub-Saharan Africa, Central Asia, and East Asia. Depending on the country, infections may be concentrated in certain population groups (for example, injecting drug users [IDU]).

HBV and HCV belong to parenteral-transmitted infections, which means that virus is transmitted via blood and/or other body fluids upon the condition of skin or mucosal damage. Natural infection routes include sexual transmission (direct sexual contacts), vertical (mother-to-child transmission during or after birth, as well as germinal infection), domestic contacts (direct and indirect including use of common hygiene items with an infected person, etc.). Artificial routes include IDU infection when using infected materials, via medical procedures with the use of HBV- or HCV-contaminated tools, blood and blood product transfusion, etc. [34]. The transmission of HBV can be blocked by vaccination, while it is not available for HCV. The progression of liver diseases associated with parenteral viral hepatitis can be prevented by long-term suppression of viral activity with effective drugs [16].

Either pathogen can lead to both acute and chronic liver disease, and in either case, during the acute stage of infection, most people do not experience any symptoms [1]. According to global statistics, around $15-45 \%$ of $\mathrm{HCV}$-infected people can spontaneously clear the virus within 6 months after infection, without any treatment. The other $55-85 \%$ of people develop $\mathrm{CHC}$ [15]. CHB is very common in infants infected from their mothers, or before the age of 5 , when the likelihood of progressing from acute hepatitis B (AHB) to chronic hepatitis is more than $90 \%$. Infection developing at an adult age leads to chronic hepatitis in less than $5 \%$ of cases [37].

The clinical course of infection depends on several factors, including the age at the time of infection, gender, ethnicity, host genetic factors, and immune status. Viral genotype, subtype, and genomic variability of the virus are also significant factors [31, 36]. $\mathrm{HBV}$ and $\mathrm{HCV}$ are genetically heterogeneous. HBV is subdivided into 10 genotypes $(\mathrm{A}-\mathrm{J})$ and more than 40 subtypes differing in nucleotide sequence composition [25]. HCV is classified into seven genotypes (1-7); genotypes $1-4$ and 6 are subdivided into a variable number of closely related subtypes (more than 100 subtypes have now been described) [28].

HBV and HCV determinations (genotype, subtype) are crucial for a better understanding of epidemiological and virological particularities, including agent characteristics. Further, this provides addition- 
al information for decision making on antiviral therapy strategies. The genotypes and subtypes of viruses differ significantly concerning the natural course of infection, pathogenesis, modes of transmission, disease progression, treatment regimens, responses to antiviral therapy, and clinical outcome [5, 30].

It should be noted that the methods of HBV and $\mathrm{HCV}$ detection, as well as the diagnostics of the associated liver diseases in middle and low-income countries, differ fundamentally from those that are used in countries with access to high-cost technologies requiring special-purpose equipment and skilled personnel. Most of the related tests are limited to the detection of hepatitis B surface antigen ( $\mathrm{HBsAg}$ ) and antibodies to the hepatitis $\mathrm{C}$ virus (anti-HCV $\operatorname{IgG}$ ), while molecular and genetic methods providing a more accurate assessment of virus prevalence are available only in core laboratories in big cities [22]. Data on the prevalence of $\mathrm{HBV}$ and $\mathrm{HCV}$ markers in a population are bounded, as tests are frequently limited to certain groups of population - risk groups (HIV-infected people, prisoners, IDU, etc.) and groups where the prevalence of infection has a substantial impact on the health of the population (blood donors, pregnant women).

The primary global health sector strategy on viral hepatitis places particular focus on hepatitis B and C, owing to the relative public health burden they represent [35]. One of the tasks required to follow this strategy is to estimate the prevalence of $\mathrm{HBV}$ and HCV among conventionally healthy people.

Vietnam is currently one of the countries with the highest mortality rates from liver cancer associated mainly with HBV and HCV infections [9]. Vietnam is amongst the 20 countries with the highest burden of $\mathrm{HCV}$ in the world. In Vietnam, the prevalence of HCV infection varies depending on the geographical location and the target population. The prevalence of anti-HCV IgG antibodies among the population is $1.0-4.7 \%$, but is substantially higher among at-risk groups [18]. The prevalence of chronic HBV infection, as measured by the hepatitis B surface antigen (HBsAg) prevalence, is $8-20 \%$ in the general population and $31-54 \%$ in the high-risk urban population in Vietnam [11]. Predictive and model studies have predicted approximately 8 million chronic HBV cases and $58600 \mathrm{HBV}$-related liver cancers in Vietnam by 2025, and an estimated annual HBV-related mortality rate of 20000 per year by 2025 [20].

The aim of this study was to assess the prevalence of serological and molecular biological markers of viral hepatitis $\mathrm{B}$ and $\mathrm{C}$ among conditionally healthy residents of South Vietnam.

\section{Materials and methods}

The study material was represented by 397 blood serum samples collected from conditionally healthy residents of the Southern Vietnam. The examined persons denied HBV or HCV infection anamnesis. The local ethics committee approved the study. All the patients gave written informed consent to participate in the study.

The ELISA examination for $\mathrm{HBV}$ and $\mathrm{HCV}$ markers occurrence involved $\mathrm{HBsAg}$, anti-HBs IgG, anti-HBcore IgG, and anti-HCV qualitative determination (test-systems by Vector-Best, Diagnostic Systems RPC) in compliance with the manufacturer's manuals.

For primary HBV DNA and HCV RNA detection, nucleic acids were extracted from blood serum using AmpliPrime Ribo-Prep commercial kit (CRIE, Moscow). Virus presence test was executed by realtime polymerase chain reaction (PCR) with hybridization fluorescence detection using AmpliSens ${ }^{\circledR} \mathrm{HCV} /$ HBV/HIV-FL commercial kit (CRIE, Moscow).

Further, for HBV DNA detection, a PCR-based method developed by the St. Petersburg Pasteur Institute under the Rospotrebnadzor was used which allows to detect low HBV DNA concentrations in various clinical materials and use amplified products for sequence analysis, with sensitivity of $5 \mathrm{ME} /$ $\mathrm{ml}$ [4]. Therewith, HBV amplification was performed involving nested-PCR according to the Taormina Occult HBV Consensus recommendation [26]. In the first stage, asymmetric PCR with extended oligonucleotides was performed, and at the second stage, to increase the sensitivity, PCR was performed using the amplification product of the first reaction, wherein one of the nested pairs overlapping primers jointly flanking the complete $\mathrm{HBV}$ genome $(\mathrm{S}$, $\mathrm{P}, \mathrm{C}, \mathrm{X}$ genes) [3]. The nucleotide sequences of the 18 complete HBV genomes were deposited in the international GenBank database under the numbers MZ671234-MZ671251.

For HCV RNA analysis, the next stage included a reverse transcription reaction with the REVERTA-L reagent kit for cDNA synthesis from an RNA template (CRIE, Moscow), and amplification with specific primers was used to obtain sequences of viral region NS5B.

The amplification products were purified and analyzed for the fragment size and concentration. Sequencing reactions were performed according to the instructions for the ABI PRISM BigDye Terminator 3.1 reagent kit. (Applied Biosystems, USA), in triplicate, on forward and reverse primers. The ABI Prism 3500 genetic analyzer (Applied Biosystems, USA) was used to identify nucleotide sequences. The primary analysis of the obtained fragment was performed according to BLAST algorithm (http://www.ncbi.nlm.nih.qov/ BLAST) in comparison with nucleotide sequences given in GenBank international database. The obtained sequences were aligned in MEGAv.7.0 with use of ClustalW algorithm [17].

For phylogenetic tree creation and subsequent phylogenetic analysis, distances between sequences were considered by neighbour-joining allowing 
Table 1. Distribution of $\mathrm{HBV}$ and $\mathrm{HCV}$ serological markers (HBsAg, anti-HBcore IgG, anti-HBs IgG, anti-HCV) in the examined group

\begin{tabular}{|c|c|}
\hline $\begin{array}{c}\text { Revealed serological } \\
\text { markers in blood } \\
\text { serum }\end{array}$ & $\begin{array}{c}\text { The surveyed group }(\mathbf{n}=397), \\
\text { proportion of the total } \\
\text { surveyed number }\end{array}$ \\
\hline HBsAg+ & $49(12.3 \%)$ \\
\hline HBs lgG+ & $153(38.53 \%)$ \\
\hline HBcore IgG+ & $223(56.17 \%)$ \\
\hline Anti-HCV+ & $13(3.27 \%)$ \\
\hline Seronegative & $74(18.63 \%)$ \\
\hline
\end{tabular}

to optimize the tree in accordance with the balanced minimum evolution criterion; a bootstrap analysis for 1000 replicas was performed to assess the created trees reliability.

Statistical data processing was carried out using the MS Excel and Prizm 5.0 (GraphPad Software Inc.) software packages. The "exact" Clopper-Pearson interval was used to estimate statistical uncertainty. Results are represented as a median (Me) indicating 95\% confidence interval (95\% CI). Fisher exact test or Yates-corrected Chi-Squared test was used to evaluate statistical significance of numeric data obtained during the paired comparison depending on sample characteristics. Probability value $\mathrm{p}<$ 0.05 was taken as a statistical significance threshold.

\section{Results}

The age of the examined individuals ranged from 18 to 65 years. Among the conditionally healthy individuals who applied not for medical reasons, the ratio of men and women did not differ, amounting to 49.12 and $50.88 \%$ (95\% CI: 45.85-55.9\%), respectively. The sex and age structure of the surveyed group are shown in Fig. 1.

The analysis of the overall prevalence of serological markers showed that among the conditionally healthy individuals $\mathrm{HBsAg}$ and anti-HCV antibodies were detected in $12.3 \%$ (95\% CI: 9.27-15.99\%) and $3.27 \%$ (95\% CI: $1.76-5.53 \%$ ) of individuals, respec-

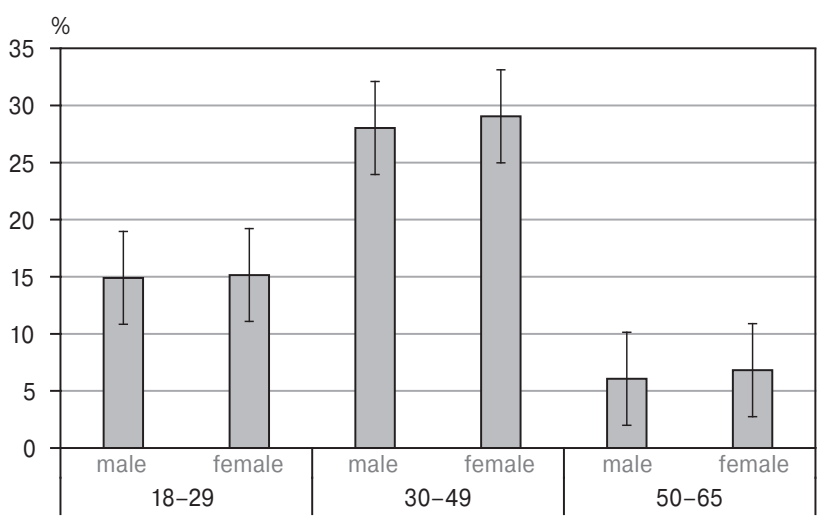

Figure 1. Age- and sex-related sample distribution tively. The results of the distribution analysis for HBV and HCV markers in the examined group are shown in the Table 1.

When analyzing the occurrence of markers in the group of conventionally healthy patients, depending on gender and age, it was shown that among HBsAg-positive individuals, men prevailed (75.5\%) compared with women (24.5\%). Thus, in the group of conventionally healthy individuals, the prevalence of HBsAg in men (19.1\%) significantly exceeded that in women $(5.9 \%), \chi^{2}=14.688$ with $\mathrm{p}=0.0001, \mathrm{df}=1$, calculated odds ratio OR $=3.751$ (95\% CI: $1.892-$ 7.439). We did not find any dependence of the antiHCV Ig G distribution on sex and age.

In the examination of 397 clinical blood serum samples for HBV DNA and HCV RNA presence using AmpliSens ${ }^{\circledR}$ HCV/HBV/HIV-FL commercial kit, the HCV was detected in 7 samples, which accounted for $1.76 \%$ (95\% CI: $0.71-3.6 \%$ ), and HBV detected in 42 of HBsAg-positive patients, which accounted for $10.58 \%$ (95\% CI: 7.73-14.03\%).

Using a method that detects HBV DNA at low viral load, HBV was detected in all HBsAg-positive samples, as well as in $58 \mathrm{HBsAg}$-negative samples, which amounted to $14.61 \%$ (95\% CI: $11.28-18.47 \%$ ). Thus, among conditionally healthy patients, taking into account HBsAg-positive and negative samples, DNA HBV was detected in 26.95\% (95\% CI: 22.65-31.6\%).

Research on HBV and HCV genovariant prevalence in different regions of the world have been actively carried out from the moment of the genotypes' discovery until the present. All genotypes and serotypes have different geographic distribution, which is changing very slowly with time reflecting viral propagation paths related to human migration, as well as possible different geographical origins of different genotypes, which allows using them as epidemiological markers [27]. Therewith, in most regions with rare exceptions, 1-2 prevailing genotypes and several minor ones are circulating including those imported from other areas [28]. The tendency observed over the last years to prevalence displacement of one or another HBV or HCV genotype in various geographic areas due to international contact development, labor migration flows, especially from the regions with high hepatotropic virus prevalence, makes clinicians and epidemiologists pay focused attention to the hepatitis B and C epidemiological situation, not only in their region, but also in neighboring ones [6].

For further HCV analysis, sequencing of the NS5B viral regions of 7 samples (100\%) from a group of apparently healthy patients was carried out. Phylogenetic analysis showed that all isolates of the conventionally healthy group belong to genotype 6 , subtype 6 a $(100 \%)$. Phylogenetic relationships between the examined $\mathrm{HCV}$ isolates from conventionally healthy patients, and reference sequences from the GenBank international database are shown in Fig. 2. 
Phylogenetic analysis of HBV $(n=107)$ showed that the prevalence of HBV genotype B (73.84\%) compared to genotype $\mathrm{C}(26.16 \%)$. With regard to the deep typing results, subtype B4 prevalence is $64.49 \%$. Subtypes C1 (14.95\%), B2 (9.35\%), C2 (6.54\%), C3 (0.93\%), and C5 (3.74\%) were also identified. Phylogenetic relationships between the examined HBV isolates from conventionally healthy patients, and reference sequences from the GenBank international database are shown in Fig. 3.

\section{Discussion}

Out of 397 plasma samples, 13 (3.27\%) were with anti-HCV antibodies and 7 (1.76\% of the entire group) of them were confirmed RNA HCV. Our results do not contradict other relevant studies. The prevalence of anti-HCV in Vietnam is estimated to be $6.1 \%$. However, the prevalence is not uniform throughout the country and in different groups. Hence, the anti$\mathrm{HCV}$ antibody rate in blood donors is: $20.6 \%$ in $\mathrm{Ho}$ Chi Minh City in Southern Vietnam; 0.8\% in Hanoi in Northern Vietnam; 9\% in individuals without liv-

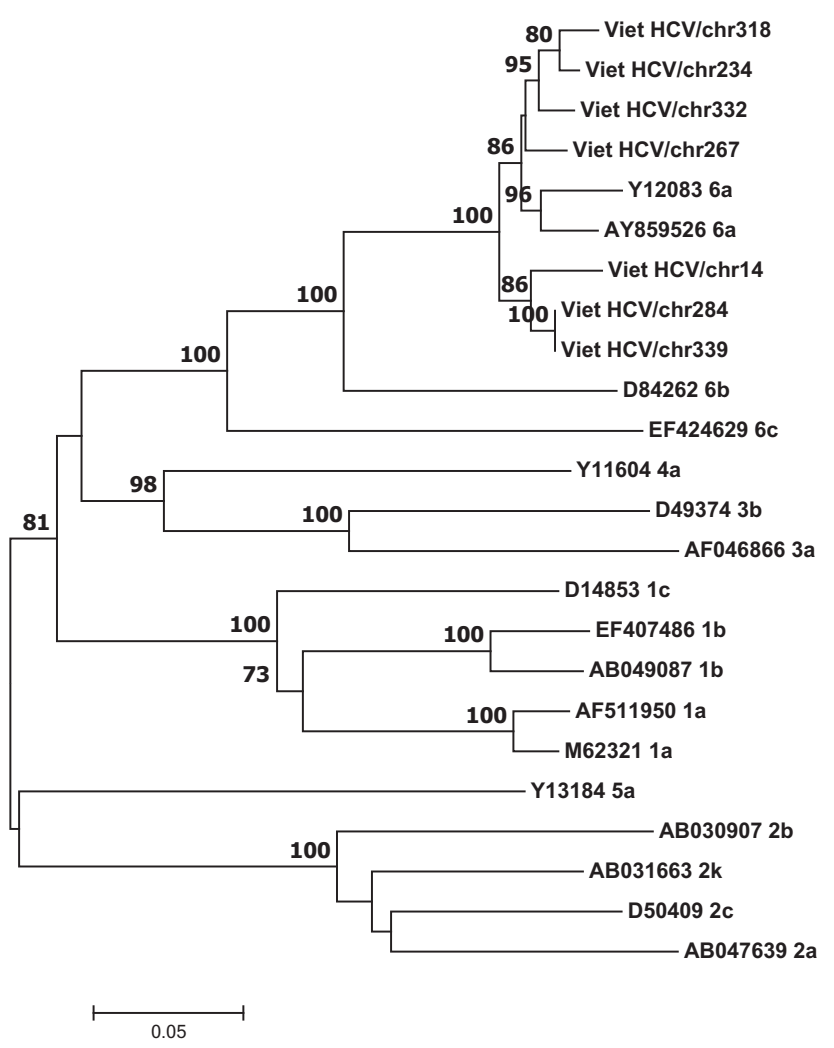

Figure 2. Phylogenetic analysis of NS5B regions $\mathrm{HCV}$ nucleotide sequences isolated from apparently healthy residents of the Socialist Republic of Vietnam (Southern Vietnam) in comparison with the reference sequences retrieved from the international GenBank database

Notes. Reference sequences are designated with GenBank codes indicating the genotype/subgenotype. Bootstrap values higher than $70 \%$ based on 1000 replications are shown at branching points.

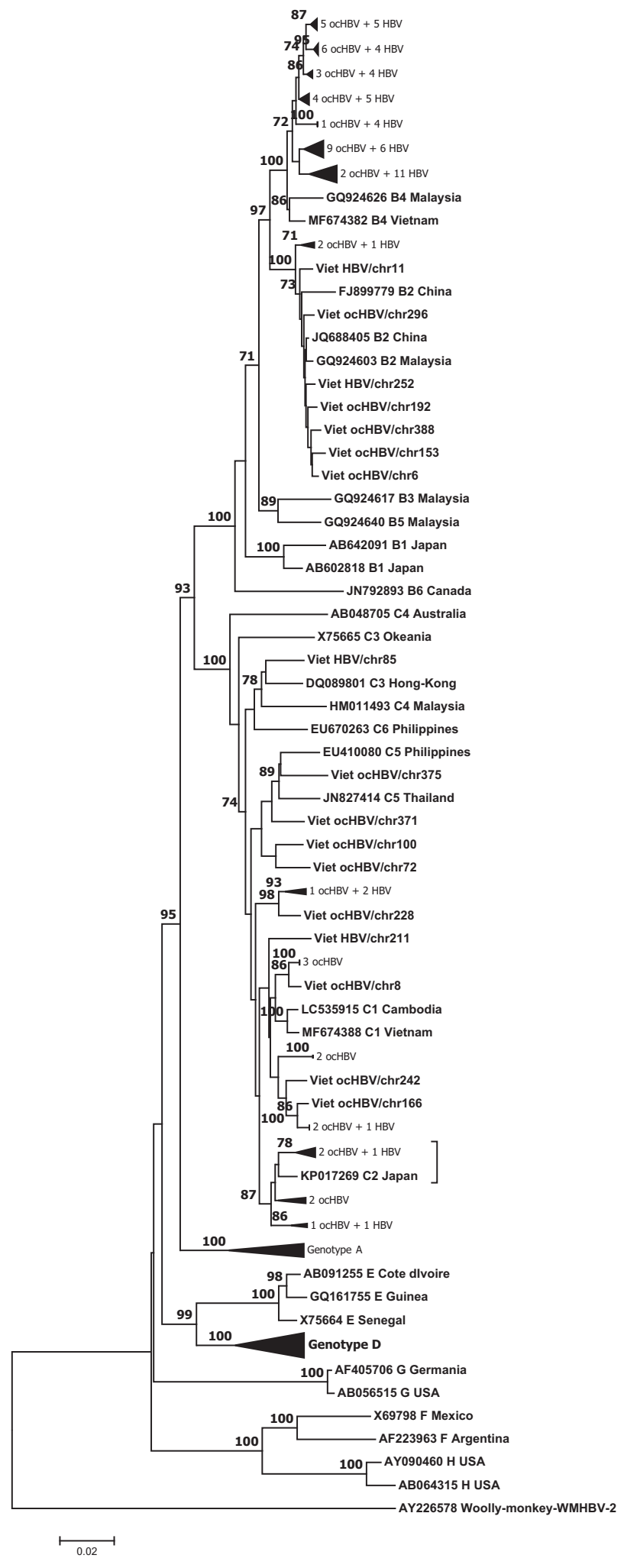

Figure 3. Phylogenetic analysis of HBV genome nucleotide sequences isolated from apparently healthy residents of the Socialist Republic of Vietnam (Southern Vietnam) in comparison with the reference sequences retrieved from the international GenBank database

Notes. Reference sequences are designated with GenBank codes indicating the genotype/subgenotype. Woolly monkey HVB (AY226578) was used as an outgroup. Bootstrap values higher than $70 \%$ based on 1000 replications are shown at branching points. 


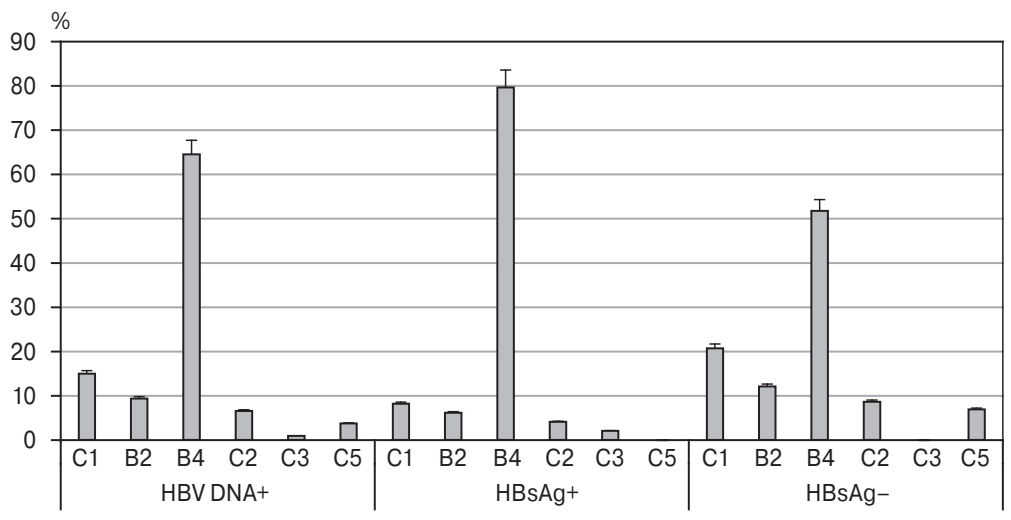

Figure 4. Distribution of HBV subtypes among HBsAg-positive and negative samples

er disease in Ho Chi Minh City; and 4\% in Hanoi; 22.9-89.0\% in HIV-infected individuals; and 74.0$87.0 \%$ in IDU [18].

We did not reveal any dependence of the antiHCV IgG distribution on sex or age, although there is data in the literature on an increase in the prevalence of HCV antibodies in people over 50 in the south of Vietnam [9].

Our findings showed that only subtype HCV 6a is presented in Southern Vietnamese conditionally healthy residents, and we did not find any genotype 1 . Our results contradict studies according to which genotypes 1 and 6 are widespread in the southern region of Vietnam, but the prevalence of one or the other genotype differs in different sources. For example, some report a predominance of genotype 6 among blood donors and in the general population [8]; others report a predominance of genotype 1, in particular $1 \mathrm{~b}(58 \%)$, followed by genotype $6 \mathrm{a}(17 \%)$, among patients with liver disease [19]. The genotype prevalence among conditionally healthy persons has never been clearly determined. Although Vietnam is among those countries in which genotype 6 variants were first detected, it cannot be argued that only genotype $6 \mathrm{a}$ is common among conventionally healthy individuals. We assume that the identification only one of subtype in the surveyed group is associated with limited sample size. An indirect confirmation of this is the work of Le Ngoc C. et al. In their study, genotype 6 prevailed in patients with chronic HCV monoinfection $(44.4 \%)$ compared with patients with HIV + HCV coinfection [18]. It was also shown that more than half of the Vietnamese patients who lived in Ho Chi Minh City were infected with genotype 6 variants, and the reason why these $\mathrm{HCV}$ variants are cir- culating in this limited geographical region remains unknown [24]. Regarding other countries, subtype 6 a circulate in South-East Asia including Thailand, Myanmar, Laos PDR and in the South-China territories of Hong-Kong and Macau, as well as in China's southernmost provinces of Yunnan and Guangxi [23].

The prevalence values of $\mathrm{HBsAg}$, anti-HBs IgG, and anti-HBcore IgG in the study groups were 12.34 , 38.53 , and $56.17 \%$, respectively. Thus, over $78 \%$ (95\% CI: $73.69-82.06 \%$ ) have been exposed to the virus, which is confirmed by anti-HBcore $\mathrm{IgG}$ and anti-HBs IgG antibody detection. A similar picture of HBV serological marker occurrence in the population is presented in the works of other researchers. For example, among of 509 adults, comprised of 230 men $(45.2 \%)$ and 279 women $(54.8 \%)$, prevalence of $\mathrm{HBsAg}$, anti-HBs IgG and anti-HBcore IgG were $15.3,60.3$ and $71.7 \%$, respectively [9]. In another study, when analyzing serological markers in 837 samples from patients aged 16-82 years, prevalence of anti-HBcore and $\mathrm{HBsAg}$ were $68.2 \%$ and $19.0 \%$, respectively [21]. In our study, the prevalence of HBsAg was higher in males than females.

The PCR technique is widely used for molecular diagnostics of HBV. Testing performed with the AmpliSens ${ }^{\circledR}$ HBV-FL commercial kit showed that the HBV DNA prevalence in the group (10.57\%) is comparable with the $\mathrm{HBsAg}$ detection frequency (12.34\%). Nevertheless, both techniques are not sufficiently sensitive, and it is proved by the detection of HBV DNA in another 58 seronegative patients (14.61\% of total samples) when we used the technique developed at the Saint Petersburg Pasteur Institute for detection of HBV DNA at low viral loads (Table 2). Thus, the prevalence of HBV DNA in the

Table 2. Results of HBV DNA low concentration detection in blood serum samples

\begin{tabular}{|c|c|c|c|}
\hline \multirow[b]{2}{*}{ HBV DNA } & \multirow[b]{2}{*}{$\begin{array}{l}\text { Samples number } \\
n=397(100 \%)\end{array}$} & \multicolumn{2}{|c|}{ HBsAg in blood serum samples } \\
\hline & & $\begin{array}{c}\text { HBsAg }(+) n=49 \\
{[12.34 \% \text { from } n=397(\mathrm{Cl} 95 \%:} \\
9.27-15.99 \%)]\end{array}$ & $\begin{array}{c}\text { HBsAg (-) } n=348 \\
{[87.66 \% \text { from } n=397(\mathrm{Cl} 95 \%:} \\
84.01-90.73 \%)]\end{array}$ \\
\hline HBV DNA+ & $\begin{array}{c}107(26.95 \%) \\
\text { (CI 95\%: } 22.65-31.5 \%)\end{array}$ & $\begin{array}{c}49(45.79 \%) \\
\text { (CI 95\%: 36.12-55.7\%) }\end{array}$ & $\begin{array}{c}58(54.21 \%) \\
\text { (CI95\%: 44.3-63.88\%) }\end{array}$ \\
\hline
\end{tabular}


examined group (26.95\%) exceeds the previously published prevalence rates for the virus in the region. It can be assumed that this is due to the limitation of the methods used, which do not allow detecting the HBsAg-negative form of the course of $\mathrm{CHB}$ at a low viral load.

Confidence intervals overlapping in HBV DNA detection in $\mathrm{HBV}$-positive patients indicates two independent phases of $\mathrm{CHB}$ natural progression - accompanied and non-accompanied by virus replication with active sub-genome RNA translation with HBV cccDNA persistence in hepatic cell cores, but with entire-genome RNA transcription suppression, which, however, does not evidence virus elimination.

It is known that chronic infection is characterized by persistent HBsAg presence over at least 6 months (with concomitant $\mathrm{HBeAg}$ presence or absence), and its level in blood serum constitutes the main marker for disease development risk assessment and $\mathrm{CHB}$ forecasting, as well as for HBV diagnostics in general. However, one of CHB's natural progression forms is presented by occult hepatitis B infection (OBI), which is characterized by HBV DNA persistence in liver tissue and extremely low HBV DNA concentration with undetectable HBsAg level in peripheral blood [12]. OBI development is conditioned by suppression of sub-genomic HBV RNA endonuclear transcription from the covalently closed circular HBV DNA matrix, based on which viral genome and viral proteins are synthesized [28]. The suppression may be caused by a number of factors which are not yet fully understood, including genetic traits of the virus itself and/or of its host, or by external interference. Hence, in most cases, viral replication and gene expression may be suppressed to such an extent that viral load in a patient's peripheral blood is extremely low, down to the impossibility of HBV DNA detection by standard methods, yet virus elimination does not happen under the replication suppression [26]. Despite the HBsAg absence in peripheral blood, most patients with OBI are seropositive for one or several serological markers depending on disease progression phase: anti-HBs IgG; $\mathrm{HBeAg}$; anti-HBe IgG; anti-HBcore $\mathrm{IgG}$. However, over $20 \%$ of patients are seronegative for all HBV markers [26].

Despite the considerable public healthcare problems associated with HBV in Vietnam, it should be noted that HBV detection methods and HBVrelated liver disease diagnostics in low or medium income countries significantly differ from those used in countries which have access to more advanced technologies. Most studies on this subject in Vietnam are limited to measurement of HBV surface antigen; molecular genetic methods permitting more accurate assessment of HBV prevalence and genotyping the virus are available only in large cities' central laboratories [2]. Further, there are limited data on HBV marker prevalence in the population since screening is performed predominantly in separate population groups: high-risk groups (HIV-infected persons, IDU, etc.); and in the groups, where infection prevalence significantly influences public health (blood donors, pregnant women). Occult hepatitis B infection occurrence varies around the world. However, it generally correlates with the manifest HBV form's occurrence [13]. In our study, the high OBI occurrence should be noted, which is peculiar to the regions where $\mathrm{HBV}$ is widely occurring. It should be noted that $\mathrm{HBV}$ has the highest prevalence among low-income population groups, including the rural population, while our study included mainly persons with relatively favorable social and economic position by this region's standards. We suppose that examination in poorer populations of this geographic region would indicate considerably higher rates of HBV molecular marker prevalence.

Our results of $\mathrm{HBV}$ genotyping indicate that $\mathrm{HBV}$ genotype B dominates in Southern Vietnam, followed by genotype $\mathrm{C}$. This is consistent with earlier data published in Vietnam. However, while it is known that OBI genotypes and sub-types correlate with HBV genotype distribution in a particular region [13], literature data on occult HBV epidemiologic situations in Vietnam are very few. With regard to the above, we deemed it necessary to analyze HBV genotype distribution within the obtained sample collection in two groups: in the HBsAg-positive $(n=49)$; and HBsAgnegative $(n=58)$. When comparing the distribution of genotypes in both groups, they do not differ from the distribution in the total group, but have significant differences from each other $\left(\chi^{2}=12.39, \mathrm{p}=0.0298\right.$, $\mathrm{df}=5)$. The identified HBV genotypes and subtypes are, in general, peculiar to Vietnam. However, the shown proportion considerably differs from total data. For example, among patients with chronic hepatitis undergoing treatment, genotype B $(71.43 \%)$ prevailed compared to $\mathrm{C}(27.55 \%)$; one isolate was recombinant (between $\mathrm{B}$ and $\mathrm{C}$ ). Among the isolates of genotype B, $92.86 \%$ were subgenotype B4, with $7.14 \%$ - B2. The others: $92.6 \%$ of subgenotype C belongs to $\mathrm{C} 1 ; 3.7 \%$ - subgenotype $\mathrm{C} 2$; and the remaining $3.7 \%-\mathrm{C} 3$ [32]. Our results of HBV genotyping indicate that $\mathrm{HBV}$ genotype $\mathrm{B}$ occurrence frequency among $\mathrm{HBsAg}$-positive individuals $(85.72 \%)$ is much closer to the data of other researchers $(71.43 \%$ among patients with $\mathrm{CHB}$ or $75.3 \%$ among randomly sampled individuals) [9, 32], than the corresponding frequency among OBI patients $(63.79 \%)$. Interestingly, a lower representation of genotype $\mathrm{B}(67.8 \%)$ and high genotype $\mathrm{C}(27.9 \%)$, which is similar to our results for OBI patients, was shown among $\mathrm{CHB}$ patients in Northern Vietnam [33]. Our study identified that subtype B4 occurrence frequency was significantly lower $(51.72 \%)$, and that of subtypes C1 (20.69\%) and B2 (12.07\%) among OBI was higher than the occurrence of those among HBsAg-positive individuals: 79.6, 8.16, and $6.12 \%$, respectively. The distribution of HBV genotypes/subtypes in groups is shown in Fig. 4. 
While it was shown that in Vietnam, genotype C has a higher load than genotype $\mathrm{B}$ and is associated with more severe liver diseases [33], while among the HBsAg-negative samples we examined, genotype $\mathrm{C}$ isolates are presented with a significantly lower viral load. It can be assumed that the diagnostic methods commonly used in the region do not allow identifying these cases. Due to this, in the cases described in the literature, the prevalence of HBV genotype $\mathrm{C}$ is somewhat lower than was found in our study. In addition, in our study, a significant number of C5 subtype samples (3.74\%) were identified among HBsAgnegative samples. Previously, cases of HBV C5 detection were reported, but in single quantities, when reported that HBV subtype B4 $(82.6 \%)$ predominated in at-risk groups, and other genotypes detected included B2 (2.7\%), C1 (14.6\%) and C5 (0.5\%) [10].

Nevertheless, when evaluating the HBV diversity pattern in the entire examined group material, a close genetic relationship of manifest $\mathrm{CHB}$ and OBI isolates became apparent, which also indicates OBI prevalence in the region. It should be noted that all HBV subtypes presented in the surveyed group are also common in neighboring countries. However, in Cambodia, genotype C $(80.49 \%)$ was abundantly found throughout the whole of Cambodia, while genotype B (19.51\%) was exclusively found in regions bordering Vietnam [14]. In Thailand, the majority of OBI samples were HBV genotype C (81.3\%), with $6.3 \%$ of samples being genotype $\mathrm{B}$, although genotype I was also detected [8]. In Laos, multiple genotypes and subtypes cocirculate and many recombinant viral forms are present, including subtypes B1,
B2, B4, C1, C5, I1, and I2 [5]. On the other hand, the demonstrated HBV subtype distribution and similarity between some of them and isolates from other Asian countries are evidence of high irregularity of their prevalence in Vietnam.

Despite their rarity, cases of mixed infection and recombination have been reported in Vietnam. In our study, we could neither detect viral genome recombination nor cases of coinfection with different HBV genotypes. Our limited number of samples might account for the apparent absence of either recombination or coinfection.

It should be noted that the results obtained here for conventionally healthy patients cannot be considered representative population data since we estimated the prevalence of viral hepatitis markers in the population visiting hospitals; some socioeconomic or occupational groups may have more reasons to visit hospitals than others. Thus, these samples may represent individuals with a higher risk of infection in general, and therefore may not be representative of the population.

\section{Conclusion}

Our work has shown a high prevalence of parenteral viral hepatitis markers among conditionally healthy residents of southern Vietnam. Particular attention should be paid to the high prevalence of $\mathrm{HBs} \mathrm{Ag}$-negative $\mathrm{HBV}$ in the region, which indicates the insufficiency of the currently used methods both for detection of the virus and for infection prevention (prophylaxis).

\section{References}

1. Мукомолов С.Л., Левакова И.А. Эпидемиологическая характеристика хронических вирусных гепатитов в Российской Федерации в 1999-2009 гг. // Инфекция и иммунитет. 2011. Т. 1, № 3. C. 255-262. [Mukomolov S.L., Levakova I.A. Epidemiological characteristics of chronic viral hepatitis in the Russian Federation in 1999-2009. Infektsiya $i$ immunitet $=$ Russian Journal of Infection and Immunity, 2011, vol. 1, no. 3, pp. 255-262. (In Russ.)] doi: 10.15789/2220-7619-2011-3-255-262

2. Останкова Ю.В., Найденова Е.В., Серикова Е.Н., Щемелев А.Н., Валутите Д.Э., Зуева Е.Б., Хуйнх Х.К.Т., Семенов А.В. К вопросу о коинфицировании вирусами Денге и возбудителями гемоконтактных инфекций в Социалистической Республике Вьетнам // Проблемы особо опасных инфекций. 2021. № 3. C. 6-12. [Ostankova Yu.V., Naidenova E.V., Serikova E.N., Shchemelev A.N., Valutite D.E., Zueva E.B., Huynh H.K.T., Semenov A.V. On the question of with Dengue viruses and pathogens of hemocontact infections coinfection in the Socialist Republic of Vietnam. Problemy osobo opasnykh infektsiy $=$ Problems of Particularly Dangerous Infections, 2021, no. 3, pp. 6-12. (In Russ.)] doi: 10.21055/0370-1069-2021-3-6-12

3. Останкова Ю.В., Семенов А.В., Тотолян Арег А. Выявление вируса гепатита В в плазме крови при низкой вирусной нагрузке // Клиническая лабораторная диагностика. 2019. Т. 64, № 10. C. 635-640. [Ostankova Yu.V., Semenov A.V., Totolian Areg A. Hepatitis B virus identification in a blood plasma at a low viral load. Klinicheskaya Laboratornaya Diagnostika $=$ Russian Clinical Laboratory Diagnostics, 2019, vol. 64, no. 10, pp. 635-640. (In Russ.)] doi: 10.18821/0869-2084-2019-64-10-635-640

4. Серикова Е.Н., Семенов А.В., Останкова Ю.В., Тотолян Арег А. Метод выявления вируса гепатита В в плазме крови при низкой вирусной нагрузке с использованием ПЦР в режиме реального времени // Клиническая лабораторная диагностика. 2021. T. 66, № 1. C. 59-64. [Serikova E.N., Semenov A.V., Ostankova Yu.V., Totolian Areg A. Hepatitis B virus identification in a blood plasma at a low viral load by PCR Real Time. Klinicheskaya Laboratornaya Diagnostika = Russian Clinical Laboratory Diagnostics, 2021, vol. 66, no. 1, pp. 59-64. (In Russ.)] doi: 10.18821/0869-2084-2021-66-1-59-64

5. Andernach I.E., Jutavijittum P., Samountry B., Yousukh A., Thammavong T., Hübschen J.M., Muller C.P. A high variability of mixed infections and recent recombinations of hepatitis B virus in Laos. PLoS One, 2012, vol. 7, no. 2: e30245. doi: 10.1371/ journal.pone.0030245

6. Bissinger A.L., Fehrle C., Werner C.R., Lauer U.M., Malek N.P., Berg C.P. Epidemiology and genotyping of patients with chronic hepatitis B: genotype shifting observed in patients from Central Europe. Pol. J. Microbiol., 2015, vol. 64, no. 1, pp. 15-21.

7. Cavalcante L.N., Lyra A.C. Predictive factors associated with hepatitis C antiviral therapy response. World J. Hepatol., 2015, vol. 7, no. 12, pp. 1617-1631. doi: 10.4254/wjh.v7.i12.1617 
8. Chamni N., Louisirirotchanakul S., Oota S., Sakuldamrongpanish T., Saldanha J., Chongkolwatana V., Phikulsod S. Genetic characterization and genotyping of hepatitis B virus (HBV) isolates from donors with an occult HBV infection. Vox Sang, 2014, vol. 107, no. 4, pp. 324-32. doi: 10.1111/vox.12178

9. Do S.H., Yamada H., Fujimoto M., Ohisa M., Matsuo J., Akita T., Katayama K., Van Nguyen N., Miyakawa Y., Tanaka J. High prevalences of hepatitis B and C virus infections among adults living in Binh Thuan province, Vietnam. Hepatol. Res., 2015, vol. 45, no. 3, pp. 259-268. doi: 10.1111/hepr. 12350

10. Dunford L., Carr M.J., Dean J., Nguyen L.T., Ta Thi T.H., Nguyen B.T., Connell J., Coughlan S., Nguyen H.T., Hall W.W., Thi L.A. A multicentre molecular analysis of hepatitis B and blood-borne virus coinfections in Viet Nam. PLoS One, 2012, vol. 7, no. 6: e39027. doi: 10.1371/journal.pone.0039027

11. Gish R.G., Bui T.D., Nguyen C.T., Nguyen D.T., Tran H.V., Trinh H.N.; International Group for Liver Health in Viet Nam. Liver disease in Viet Nam: screening, surveillance, management and education: a 5-year plan and call to action. J. Gastroenterol. Hepatol., 2012, vol. 27, no. 2, pp. 238-247. doi: 10.1111/j.1440-1746.2011.06974.x

12. Guo J.T., Guo H. Metabolism and function of hepatitis B virus cccDNA: Implications for the development of cccDNA-targeting antiviral therapeutics. Antiviral Res., 2015, vol. 122, pp. 91-100. doi: 10.1016/j.antiviral.2015.08.005

13. Kishk R., Atta H.A., Ragheb M., Kamel M., Metwally L., Nemr N. Genotype characterization of occult hepatitis B virus strains among Egyptian chronic hepatitis C patients. East Mediterr. Health J., 2014, vol. 20, no. 2, pp. 130-138.

14. Ko K., Takahashi K., Nagashima S., Yamamoto C., Ork V., Sugiyama A., Akita T., Ohisa M., Chuon C., Hossain M.S., Mao B., Tanaka J. Existence of hepatitis B virus surface protein mutations and other variants: demand for hepatitis B infection control in Cambodia. BMC Infect. Dis., 2020, vol. 20, no. 1: 305. doi: 10.1186/s12879-020-05025-3

15. Korean Association for the Study of the Liver. KASL clinical practice guidelines: management of chronic hepatitis B. Clin. Mol. Hepatol., 2016, vol. 22, no. 1, pp. 18-75. doi: 10.3350/cmh.2016.22.1.18

16. Korean Association for the Study of the Liver. KASL clinical practice guidelines: management of hepatitis C. Clin Mol Hepatol., 2016, vol. 22, no. 1, pp. 76-139. doi: 10.3350/cmh.2016.22.1.76

17. Kumar S., Stecher G., Tamura K. MEGA7: Molecular Evolutionary Genetics Analysis version 7.0 for bigger datasets. Mol. Biol. Evol., 2016, vol. 33, no. 7, pp. 1870-1874. doi: 10.1093/molbev/msw054

18. Le Ngoc C., Tran Thi Thanh T., Tran Thi Lan P., Nguyen Mai T., Nguyen Hoa T., Nghiem My N., Le Van T., Le Manh H., Le Thanh P., Nguyen Van Vinh C., Thwaites G., Cooke G., Heilek G.M., Shikuma C., Le T., Baker S., Rahman M.; VIZIONS Consortium. Differential prevalence and geographic distribution of hepatitis $\mathrm{C}$ virus genotypes in acute and chronic hepatitis $\mathrm{C}$ patients in Vietnam. PLoS One, 2019, vol. 14, no. 3: e0212734. doi: 10.1371/journal.pone.0212734

19. Li C., Yuan M., Lu L., Lu T., Xia W., Pham V.H., Vo A.X.D., Nguyen M.H., Abe K. The genetic diversity and evolutionary history of hepatitis C virus in Vietnam. Virology, 2014, vol. 468-470, pp. 197-206. doi: 10.1016/j.virol.2014.07.026

20. Nguyen V.T., Law M.G., Dore G.J. An enormous hepatitis B virus-related liver disease burden projected in Vietnam by 2025. Liver Int., 2008, vol. 28, no. 4, pp. 525-531. doi: 10.1111/j.1478-3231.2007.01646.x

21. Nguyen V.T., McLaws M.L., Dore G.J. Highly endemic hepatitis B infection in rural Vietnam. J. Gastroenterol. Hepatol., 2007, vol. 22, no. 12, pp. 2093-2100. doi: 10.1111/j.1440-1746.2007.05010.x

22. Norder H., Couroucé A.-M., Coursaget P., Echevarria J.M., Lee S.-D., Mushahwar I.K., Robertson B.H., Locarnini S., Magnius L.O. Genetic diversity of hepatitis B virus strains derived worldwide: genotypes, subgenotypes, and HBsAg subtypes. Intervirology, 2004, vol. 47, no. 6, pp. 289-309. doi: 10.1159/000080872

23. Pham D.A., Leuangwutiwong P., Jittmittraphap A., Luplertlop N., Bach H.K., Akkarathamrongsin S., Theamboonlers A., Poovorawan Y. High prevalence of Hepatitis C virus genotype 6 in Vietnam. Asian Pac J. Allergy Immunol., 2009, vol. 27, no. 2-3, pp. 153-160.

24. Pham V.H., Nguyen H.D., Ho P.T., Banh D.V., Pham H.L., Pham P.H., Lu L., Abe K. Very high prevalence of hepatitis C virus genotype 6 variants in southern Vietnam: large-scale survey based on sequence determination. Jpn J. Infect Dis., 2011, vol. 64, no. 6, pp. 537-539.

25. Pourkarim M.R., Amini-Bavil-Olyaee S., Kurbanov F., Van Ranst M., Tacke F. Molecular identification of hepatitis B virus genotypes/subgenotypes: revised classification hurdles and updated resolutions. World J. Gastroenterol., 2014, vol. 20, no. 23, pp. 7152-7168. doi: 10.3748/wjg.v20.i23.7152

26. Raimondo G., Locarnini S., Pollicino T., Levrero M., Zoulim F., Lok A.S.; Taormina Workshop on Occult HBV Infection Faculty Members. Update of the statements on biology and clinical impact of occult hepatitis B virus infection. J. Hepatol., 2019, vol. 71, no. 2, pp. 397-408. doi: 10.1016/j.jhep.2019.03.034

27. Schweitzer A., Horn J., Mikolajczyk R.T., Krause G., Ott J.J. Estimations of worldwide prevalence of chronic hepatitis B virus infection: a systematic review of data published between 1965 and 2013. Lancet, 2017, vol. 386, no. 10003, pp. 1546-1555. doi: 10.1016/S0140-6736(15)61412-X

28. Smith D.B., Bukh J., Kuiken C., Muerhoff A.S., Rice C.M., Stapleton J.T., Simmonds P. Expanded classification of hepatitis C virus into 7 genotypes and 67 subtypes: updated criteria and genotype assignment web resource. Hepatology, 2014, vol. 59, no. 1, pp. 318-327. doi: 10.1002/hep.26744

29. Stasi C., Silvestri C., Voller F. Emerging trends in epidemiology of hepatitis B virus infection. J. Clin. Transl. Hepatol., 2017, vol. 5, no. 3, pp. 272-276. doi: 10.14218/JCTH.2017.00010

30. Tanwar S., Dusheiko G. Is there any value to hepatitis B virus genotype analysis? Curr. Gastroenterol. Rep., 2012, vol. 14, no. 1, pp. 37-46. doi: 10.1007/s11894-011-0233-5

31. Te H.S., Jensen D.M. Epidemiology of hepatitis B and C viruses: a global overview. Clin Liver Dis., 2010, vol. 14, no. 1, pp. 1-21. doi: 10.1016/j.cld.2009.11.009

32. Trang N.H., That B.T.T., Thanh T.T.T., Chau L.N., Thanh T.T., Ngoc N.M., Hung N.M., Chau N.V.V., Rahman M. A17 Molecular characteristics of hepatitis B virus (HBV) isolated from chronic hepatitis B patients in South Vietnam. Virus Evol., 2017, vol. 3, no. 1: vew036.016. doi: 10.1093/ve/vew036.016 
33. Truong B.X., Seo Y., Yano Y., Ho P.T., Phuong T.M., Long D.V., Son N.T., Long N.C., Kato H., Hayashi Y., Trach N.K., Kasuga M. Genotype and variations in core promoter and pre-core regions are related to progression of disease in HBV-infected patients from Northern Vietnam. Int J. Mol. Med., 2007, vol. 19, no. 2, pp. 293-299. doi: 10.3892/ijmm.19.2.293

34. WHO. Prevention and control of viral hepatitis infection: frame work for global action 2012. Geneva: WHO, 2012. 24 p.

35. WHO. Sixty-ninth world health assembly provisional agenda item 15.1. Draft global health sector strategies. Viral hepatitis, 20162021. Geneva: WHO, 2016. 44 p.

36. Yano Y., Azuma T., Hayashi Y. Variations and mutations in the hepatitis B virus genome and their associations with clinical characteristics. World J. Hepatol., 2015, vol. 7, no. 3, pp. 583-592. doi: 10.4254/wjh.v7.i3.583

37. Yim H.J., Lok A.S. Natural history of chronic hepatitis B virus infection: what we knew in 1981 and what we know in 2005. Hepatology, 2006, vol. 43, no. S1, pp. S173-S181. doi: 10.1002/hep.20956

\section{Авторы:}

Останкова Ю.В., к.б.н., старший научный сотрудник лаборатории молекулярной иммунологии ФБУН НИИ эпидемиологии и микробиологии имени Пастера,

Санкт-Петербург, Россия;

Семенов А.В., д.б.н., директор Екатеринбургского научноисследовательского института вирусных инфекций ФБУН ГНЦ ВБ «Вектор» Роспотребнадзора, г. Екатеринбург, Россия; Зуева Е.Б., к.б.н., биолог отделения диагностики ВИЧ-инфекции и СПИД-ассоциированных заболеваний ФБУН НИИ эпидемиологии и микробиологии имени Пастера, Санкт-Петербург, Россия;

Серикова Е.Н., научный сотрудник лаборатории вирусологии и иммунологии ВИЧ-инфекции ФБУН НИИ эпидемиологии и микробиологии имени Пастера, Санкт-Петербург, Россия; Щемелев А.Н., младший научный сотрудник лаборатории вирусологии и иммунологии ВИЧ-инфекции, аспирант ФБУН НИИ эпидемиологии и микробиологии имени Пастера, Санкт-Петербург, Россия;

Валутите Д.Э., врач клинико-лабораторной диагностики отделения диагностики ВИЧ-инфекции и СПИД-

ассоциированных заболеваний ФБУН НИИ эпидемиологии и микробиологии имени Пастера, Санкт-Петербург, Россия;

Хуйнх Х.К.Т.,научный сотрудник лаборатории медицинских анализов Института имени Пастера в г. Хошимин, г. Хошимин, Вьетнам;

Егорова С.А., д.м.н., зам. директора по инновациям ФБУН НИИ эпидемиологии и микробиологии имени Пастера, Санкт-Петербург, Россия;

Тотолян Арег А., академик РАН, д.м.Н., профессор, директор ФБУН НИИ эпидемиологии и микробиологии имени Пастера, Санкт-Петербург, Россия.

\section{Authors:}

Ostankova Yu.V., PhD (Medicine), Senior Researcher, Laboratory of Molecular Immunology, St. Petersburg Pasteur Institute, St. Petersburg, Russian Federation;

Semenov A.V., PhD, MD (Biology), Director of Ekaterinburg Research Institute of Viral Infections of SRC VB Vector of the Federal Service for Surveillance on Consumer Rights Protection and Human Wellbeing, Ekaterinburg, Russian Federation;

Zueva E.B., PhD (Biology), Biologist, Department of Diagnostics of HIV Infection and AIDS-associated Diseases, St. Petersburg Pasteur Institute, St. Petersburg, Russian Federation; Serikova E.N., Researcher, Laboratory of Virology and Immunology of HIV Infection, St. Petersburg Pasteur Institute, St. Petersburg, Russian Federation;

Schemelev A.N., Junior Researcher, Laboratory of Virology and Immunology of HIV Infection, Postgraduate Student, St. Petersburg Pasteur Institute, St. Petersburg, Russian Federation; Valutite D.E., Clinical Laboratory Diagnostics Doctor, Department of Diagnostics of HIV Infection and AIDS-associated Diseases, St. Petersburg Pasteur Institute, St. Petersburg, Russian Federation; Huynh H.K.T., Researcher, Medical Analysis Laboratory Department, Ho Chi Minh Pasteur Institute, Ho Chi Minh City, Vietnam;

Egorova S.A., PhD, MD (Medicine), Deputy Director for Innovation, St. Petersburg Pasteur Institute, St. Petersburg, Russian Federation; Totolian Areg A., RAS Full Member, PhD, MD (Medicine), Professor, Director of St. Petersburg Pasteur Institute, St. Petersburg, Russian Federation. 